\begin{tabular}{lc}
\hline & ANNALES \\
& UNIVERSITATIS MARIAE CURIE-SKŁODOWSKA \\
LOL. V & SECTIO N \\
\hline
\end{tabular}

ISSN: 2451-0491 - e-ISSN: 2543-9340 - CC-BY 4.0 • DOI: 10.17951/en.2020.5.313-324

\title{
Sentymentalny wymiar „napoleońskich” wspomnień Franciszka Wiktora Dmochowskiego
}

\author{
A Sentimental Aspect of Franciszek Wiktor \\ Dmochowski’s “Napoleonic” Memoirs
}

\author{
Artur Timofiejew \\ Uniwersytet Marii Curie-Skłodowskiej w Lublinie. Wydział Humanistyczny \\ pl. Marii Curie-Skłodowskiej 4A, 20-031 Lublin, Polska \\ a.timofiejew@umcs.pl \\ https://orcid.org/0000-0002-5742-1362
}

\begin{abstract}
The article focuses on showing memoirs of Napoleonic era - Franciszek Wiktor Dmochowski's Letters from a Former Sergeant Major (Pol. Pisma bytego wachmistrza; 1843) - as a sign of vivacity of sentimentalism at the end of early part of the $19^{\text {th }}$ century. Two-strip structure of narration - recording of historical data and recording of subjective emotional experiences shows accordance with typical sentimental regulation: the more intensive inner life the richer description of external reality. The motif of unfortunate love plays an important part in carrying a recollection. Apart of sentimentally conventionalized narrative structure the work of Dmochowski is perceived by its editor, Andrzej Edward Koźmian, in the way that indicates a publishing manner of sentimentalism. The publisher in his Preface creates the author of memoirs according with sentimental anthropological patterns and explains this creation referring sentimental axiology which he consents to.
\end{abstract}

Keywords: Franciszek Wiktor Dmochowski; Andrzej Edward Koźmian; memoirs of Napoleonic era; sentimentalism 


\begin{abstract}
Abstrakt. Celem artykułu jest ukazanie pamiętnika z epoki napoleońskiej - Pism byłego wachmistrza (1843) Franciszka Wiktora Dmochowskiego - jako jednego z przejawów żywotności sentymentalizmu w latach 40. XIX wieku. Dwupasmowa struktura narracji: zapis faktów historycznych i zapis przeżyć osobistych - wykazuje typową dla sentymentalizmu prawidłowość: im bardziej intensywne jest doświadczanie uczuć, tym bogatsza relacja o zewnętrznym wobec podmiotu świecie. We wspomnieniach Dmochowskiego główną rolę w prowadzeniu narracji odgrywa motyw nieszczęśliwej miłości. Niezależnie od sentymentalnie skonwencjonalizowanej struktury utwór Dmochowskiego jest postrzegany przez jego wydawcę, Andrzeja Edwarda Koźmiana, w sposób typowy dla edytorskiej konwencji sentymentalizmu - wydawca kreuje w swojej przedmowie do Pism ich autora zgodnie z sentymentalnym wzorcem antropologicznym i usprawiedliwia to akceptowaną przez siebie aksjologią sentymentalną.
\end{abstract}

Słowa kluczowe: Franciszek Wiktor Dmochowski; Andrzej Edward Koźmian; pamiętnik z epoki napoleońskiej; sentymentalizm

Za zjawisko analogiczne do długiego trwania klasycyzmu w literaturze XIX stulecia należy uznać żywotność ideowych i estetycznych założeń sentymentalizmu w pierwszej połowie „wieku pary i elektryczności”. Niezależnie bowiem od genetycznie odmiennych - zarówno gdy idzie o światopogląd, jak i o wynikającą z niego koncepcję estetyki - romantycznych norm ekspresji kulturowej zazwyczaj obok nich, a często w symbiozie z nimi, funkcjonowały w tej epoce normy o rodowodzie sięgającym literackich osiągnięć Richardsona, Rousseau, Sterne'a i Goethego - autora Cierpień młodego Wertera². Funkcjonowały, jak trafnie zauważa Geoffrey Sill, przywołując opinię szkockiego romantyka Roberta Burnsa, dzięki uniwersalizmowi ich moralnego wymiaru:

Sentimentalism may be defined many ways, but Burns's letter highlights one of them: the longing after an imagined world, [...] in which sympathy, benevolence,

1 Długie trwanie sentymentalizmu w literaturze polskiej - zwłaszcza zaś w poezji - pierwszej połowy XIX w., stanowi przedmiot szczegółowej refleksji historycznoliterackiej w wielu klasycznych już dziś pracach, m.in.: Czesława Zgorzelskiego (1949), Juliusza Kleinera (1975), Teresy Kostkiewiczowej (1981). Próbę prześledzenia relacji między prądami estetycznoliterackimi kształtującymi poezję polską lat 1795-1830 podjęła ostatnio Anna Jończyk w artykule Sentymentalizm a preromantyzm (2014), akcentując - w nawiązaniu do tytułu spostrzeżeń Kleinera różnice zachodzące między oboma prądami. Badawczy ogląd epoki Mickiewicza i Słowackiego, uwzględniający kategorię dziewiętnastowieczności jako kluczową w rozpoznaniu i opisie m.in. późnego sentymentalizmu, przekraczającego cezurę 1830 roku, stanowi podstawę studium Bogusława Doparta Nasz literacki wiek XIX $i$, izmy” (2002).

2 Mimo znajdujących się w powieści młodego Goethego akcentów polemicznych wobec sentymentalizmu jako aksjologicznej podstawy określonego modelu egzystencji, Cierpienia młodego Wertera uznawano jeszcze w pierwszych dziesięcioleciach XIX wieku za dzieło literatury sentymentalnej (zob. Herrlinger 1987: 118). 
and goodness are the predominant virtues. (Sentymentalizm można definiować na wiele sposobów, ale list Burnsa uwydatnia jeden z nich: [sentymentalizm] to tęsknota za wyobrażonym światem, [...] w którym sympatia, dobroczynność i dobroć są dominującymi cnotami [przeł. A.T.]). (Sill 2016: 426)

Fundujące sentymentalny światopogląd wartości, przybierające - każda z osobna - postać cnoty, czyli wartości, która winna być praktykowana (a zatem przede wszystkim urzeczywistniana w relacji człowieka z człowiekiem i otaczającym go światem, ale także wyrażana, tj. opisywana, głoszona, postulowana), ze względu na swoją ponadczasową ważność stanowią, jakby mimochodem, swoisty pas transmisyjny dla sentymentalizmu między końcem XVIII wieku a początkiem i pierwszymi czterema dziesięcioleciami następnego stulecia. Żywe jeszcze w latach 40. XIX wieku kultywowanie sentymentalnej aksjologii, a więc również jej literacka i paraliteracka artykulacja, znajdowały swój wyraz w licznych utworach amatorskich, w epistolografii i pamiętnikarstwie, zazwyczaj nieprzeznaczonych do druku³. Jednym z nich, wartym bliższego przyjrzenia się z racji wyrazistego nacechowania znamionami konwencji sentymentalnej, są Pisma bytego wachmistrza w wojskach pięciu różnych mocarstw, dziś majstra krawieckiego w Przemyślu - wspomnienia spisane przez Franciszka Wiktora Dmochowskiego.

„Były wachmistrz", weteran wojen napoleońskich wywodzący się ze szlachty mazowieckiej, osiadłej pomiędzy Pułtuskiem a Ostrołęką, z rozgałęzionego rodu Dmochowskich, z którego pochodzili dwaj zasłużeni dla rozwoju literatury Franciszkowie - Ksawery i Salezy, urodził się w 1780 roku (w swoim pamiętniku zaznacza na wstępie, że w dniu klęski maciejowickiej ukończył 14 lat). Z Przemyślem związał się od 1823 roku, po otrzymaniu dymisji z armii austriackiej, i mieszkał w nim aż do śmierci w 1855 roku. Tu, w królewskim grodzie nad Sanem, przeszedł metamorfozę typową dla drobnego szlachcica wysadzonego przez „dziejowe wypadki” z siodła i klejnot szlachecki zamienił - niczym późniejszy Siekierzyński z powieści Kraszewskiego - na fartuch rzemieślnika, konkretnie zaś na igłę i nożyce krawieckie. Jako krawiec i dymisjonowany podoficer spisał na początku lat 40. swoje wspomnienia z młodości, które przypadkiem,

3 Ciekawy dziewiętnastowieczny ślad konwencji sentymentalnej i aksjologii motywującej jej zastosowanie wskazała w „napoleońskim” pamiętniku Aleksandra Fredry Trzy po trzy (powstałym między rokiem 1844 a 1854) Krystyna Czajkowska (1987: 13): „Bije z tych słów jakiś rys głęboko ludzki, uczuciowość wrażliwa na cudzą krzywdę, zrozumienie całego złożonego procesu narastania w człowieku wszelkich kompleksów czy urazów. Szczerość, z jaką Fredro czyni te wyznania, budzi szacunek [...]”. Należy w tym miejscu przypomnieć za cytowaną autorką Wstępu do Trzy po trzy, że swoje wspomnienia opatrzył Fredro kategorycznym zakazem „nie do druku” (tamże: 12). 
poszukując rozproszonych w prywatnych zasobach szesnastowiecznych wydań Bielskiego i Kochanowskiego, odkrył i przysposobił do druku Andrzej Edward Koźmian. W 1843 roku wydała je wraz z przydatkiem kilku wierszy krawca-weterana oficyna Piotra Pillera we Lwowie.

Swoje wspomnienia podzielił Dmochowski na dwie części. Pierwsza, pozbawiona nalotu sentymentalnego, jest zbiorem anegdot z życia ojca pamiętnikarza i jego bliskiego sąsiada, enigmatycznie, bez podania nazwiska, zwanego Panem Podsędkiem, druga natomiast, stanowiąca właściwy pamiętnik „wachmistrza w wojskach pięciu różnych mocarstw", przynosi zapis żołnierskich doświadczeń autora, wyniesionych z miotanej wojennymi zawieruchami Europy początku XIX wieku.

Wspomnienia wojenne Dmochowskiego obejmują okres od grudnia 1806 do kwietnia 1814 roku i tematycznie związane są z czterema kampaniami: pruską, hiszpańską, moskiewską i saską. Literacki obraz zmagań prowadzonych na różnych frontach Europy doby napoleońskiej - od Pirenejów po Moskwę - malowany jest czy też, trafniej mówiąc, szkicowany wyłącznie z perspektywy podmiotu-uczestnika wybranych przecież tylko, nie wszystkich epizodów poszczególnych kampanii. Jest to zatem obraz pełny, gdy idzie o przedstawienie tych epizodów (np. potyczka z saperami francuskimi podczas bitwy pod Pułtuskiem 26 grudnia 1806 roku czy zdobycie klasztoru trynitarzy w trakcie szturmowania Saragossy 27 stycznia 1809 roku), niezwykle zaś fragmentaryczny w odniesieniu do całościowo ujmowanych batalii lat 1806-1814. Autor wspomnień skupia swoją uwagę na własnych perypetiach - jako żołnierza w armii pruskiej (koniec roku 1806), jeńca w niewoli francuskiej (rok 1807), szasera we francuskim pułku walczącym w Hiszpanii (1808-1809) i szasera w korpusie księcia Józefa Poniatowskiego (1812-1813), ułana w armii austriackiej (1814) nie podejmując próby wpisania swoich żołnierskich przygód w szerszy kontekst militarno-politycznych okoliczności ani też nie siląc się na ocenę ich znaczenia w przebiegu danej batalii.

Najwięcej uwagi, bo niemal połowę objętości wspomnień, poświęca przemyski pamiętnikarz wydarzeniom na Półwyspie Iberyjskim, dołączając do relacji o nich rodzaj rozbudowanego wstępu, zawierającego historię zaciągnięcia się do armii francuskiej wyruszającej na front hiszpański. Znacznie skromniej przedstawia się objętość wspomnień dotyczących wojny z Rosją 1812 roku i z szóstą koalicją w latach 1813-1814, a najmniej miejsca zajmuje relacja z kampanii pruskiej 1806 roku. Przyczyny zauważalnych na pierwszy rzut oka dysproporcji w rozmiarach relacji z osobiście i, dodać wypada, czynnie, w charakterze żołnierza liniowego, odbytych kampanii szukać należy w założonej przez Dmochowskiego strukturze utrwalanych przeżyć, fundowanej na splocie relacji o faktach natury 
militarnej, zewnętrznych wobec uczestniczącego w nich i rejestrującego je w swej pamięci podmiotu, oraz relacji o stanie wewnętrznym podmiotowego „ja”, stanowiącej naiwną wprawdzie, lecz formalnie poprawną analizę podmiotowo uchwytnego doświadczenia wewnętrznego. Ów splot opowiadania o historii zewnętrznej i historii własnego „ja”, znany w wersji literackiej choćby za sprawą Grenadiera-filozofa Cypriana Godebskiego (1805) czy Dum wojownika-kochanka Andrzeja Brodzińskiego (1808), stosowany również w memuarystyce epoki napoleońskiej (np. Pamiętnik Tadeusza Zabielskiego z 1812 roku czy Dziennik moich uczuciów Antoniego Ostrowskiego z 1813 roku), mający niewątpliwie proweniencję sentymentalną, z matematyczną wręcz prawidłowością decyduje o długości poszczególnych, powiązanych z kolejnymi kampaniami, partii narracyjnych pamiętnika. Prawidłowość tę ująć by można w formule: im głębszy wgląd w sferę własnej podmiotowości, tym bardziej rozbudowana relacja o wydarzeniach zewnętrznych.

W opisie kampanii pruskiej pamiętnikarz tylko sporadycznie odsłania świat swoich przeżyć i w zgodzie z powyższą formułą lakonicznie mówi o znaczących przecież z polityczno-historycznego punktu widzenia wydarzeniach, których efektem końcowym będzie powołanie Księstwa Warszawskiego. Z kolei zapis przeżyć z kampanii hiszpańskiej obfituje zarówno w rozbudowane opisy uczuciowych doznań kształtujących wewnętrzny portret narratora, jak i - analogicznie - w szczegółowe, zgrabnie, jak zauważył wydawca pamiętnika A.E. Koźmian, udramatyzowane „raporta” z niemal codziennych „wojennych wypadków", takich jak potyczki z hiszpańskimi powstańcami, szturmowanie zamków i twierdz, rekwizycje żywności i furażu czy ochrona miejscowej ludności cywilnej przed nadużyciami francuskich żołnierzy maruderów. Wreszcie stopniowemu wygaszaniu informacji o swoim wewnętrznym „ja” towarzyszy coraz bardziej skrótowe, zmierzające wraz z postępem pamiętnikarskiej narracji ku tylko ogólnemu wzmiankowaniu przywoływanie faktów przesądzających o klęsce cesarza Francuzów - dość jeszcze dokładne relacjonowanie wyprawy na Moskwę i tragicznego w skutkach dla Wielkiej Armii odwrotu spod stolicy carów (np. „Pod Borysowem na Berezynie był koniec wszystkiemu; tam pluskali się ludzie w zamarzłej rzece [...]; mój godny kapitan poległ tam od kartaczów, ja utopiłem konia, a moje ocalenie winien byłem kuli działowej, która zrzuciła złamaną poręcz od mostu, a ta mi była pomocną do wydobycia się z wody. Przyłączywszy się do rejterujących dragonów, postępowałem ku Borysowowi” [Dmochowski 1843: 164]) przechodzi w zbiór niemal encyklopedycznych haseł, dotyczących wybranych epizodów kampanii saskiej 1813 roku (np. „Zaraz po Wielkiejnocy [1813 - uzup. A.T.] nasza mała armia podzielona była na pięć kolumn, przy ostatniej był nasz szwadron; po kilkodniowym obozowaniu ruszyliśmy w pochód ku Saksonii pod 
główną komendą jenerała naczelnego księcia Józefa [...]. Piętnastego sierpnia [1813] skończyło się armistycjum, [...] w kilka dni potem stoczyliśmy walną bitwę pod Dreznem, która powiodła się Napoleonowi, lecz to była już ostatnia z wygranych" [tamże: 182-183, 184]), by w końcu przeobrazić się w zdawkowe, przypominające zapisy w rocznikach lub w kalendarzu przywołanie istoty danego wydarzenia (np. „Nasz Vandame spodziewał się przy początku września [1813] wjechać do Pragi [...]. Tegoż dnia przechodził przez miasto [Tyrnawę - uzup. A.T.] transport Merfelda ułanów" [tamże: 184-185]).

Jeśli dokonałoby się rozdzielenia obu pasm narracji, co nie byłoby rzeczą trudną do wykonania, jako że opowieść o swoim „ja” i opowieść o wydarzeniach zewnętrznych nie przenikają się w pamiętniku, lecz właśnie przeplatają, to wówczas jeszcze bardziej widoczna stałaby się monotematyczność pierwszego $\mathrm{z}$ wymienionych pasm. Tworząca je relacja dotyczy bowiem doświadczeń wewnętrznych i refleksji będących skutkiem nieszczęśliwej miłości Dmochowskiego - jeńca wojennego, a następnie rekruta w armii francuskiej i żołnierza walczącego z Hiszpanami - zakochanego w córce bretońskiego gospodarza, u którego jako „pryzonier”, eksżołnierz pruski przymusowo pracował. Historia uczucia do czułej Adeli, opowiadana w zgodzie z podstawowymi schematami konwencji sentymentalnej (nb. traktowanej przez pamiętnikarza powierzchniowo, jako pewien schemat narracji bez podbudowy światopoglądowej), takimi jak wspólne marzenia przy świetle księżyca, ukradkowe, napawające smutkiem pocałunki, przeczucie rozstania na zawsze, ciche łzy towarzyszące uściskom dłoni, decyduje - jak wspomniano - o długości poszczególnych sekwencji całości relacji pamiętnikarskiej. I tak „pruski” odcinek opowieści, w którym - rzecz jasna - nie ma jeszcze mowy o miłości do pięknej Bretonki, jest niezwykle krótki (9 stron); sekwencja „francusko-hiszpańska”, gdzie zostały przedstawione narodziny i rozwój łączącego parę bohaterów uczucia, a także poddawanie go rozmaitym próbom (przymusowa i długotrwała rozłąka, wdzięczność i kusząca uroda uratowanych z wojennych opresji Hiszpanek, brak formalnej zgody ojca bohatera na małżeństwo z francuską wieśniaczką, zaloty młodzieńców chcących poślubić Adelę ze względu na jej posag itd.), zajmuje najwięcej stron pamiętnika (92 strony); „rosyjsko-saska” partia wspomnień, zawierająca informacje o powolnym zamieraniu tego uczucia, spowodowanym nagłą śmiercią „kobiety-anioła”, sytuuje się pod względem objętości na miejscu pośrednim pomiędzy obiema poprzednimi (49 stron).

W pamiętniku Dmochowskiego język sentymentalnego opisu historii uczucia i wywoływanych przez nie wewnętrznych doświadczeń sąsiaduje z językiem rzeczowej, ukierunkowanej na istotny z militarnego punktu widzenia konkret. Podawane są detale związane z umundurowaniem i uzbrojeniem żołnierzy, 
taktycznymi posunięciami jednostek, zastosowanym sprzętem inżynieryjnym, metodami prowadzenia walki w polu, techniką oblężniczą itd. O ile jednak język sentymentalizmu we wspomnieniach przemyskiego krawca wybrzmiewa w wersji wzorowo - rzec by można - stereotypowej, o tyle drugi z zastosowanych języków zaskakuje, mimo prostoty składniowej i niewyszukanej leksyki, świeżością stylistyczną i atrakcyjnością komunikacyjną. Wynikają one z umiarkowanego dozowania słownictwa fachowego, związanego ze sferą wojskowości (dozowanie to daje czytelnikowi pewność obcowania z autentycznym tekstem pisanym przez wojskowego, a jednocześnie nie utrudnia - jak działoby się to w przypadku przeładowania wypowiedzi terminologią fachową - rozumienia przekazywanych treści), oraz z umiejętności celnego nazywania danej rzeczy lub zjawiska, ujmującego ich najbardziej dystynktywną cechę.

Ów żołnierski sentymentalizm i prostota w sferze języka relacji wspomnieniowej, spotęgowane przez banalne w treści, wyrażone częstochowskimi rymami epigramy w rodzaju „Kto nie był szczęśliwym, / Ten nie będzie poczciwym” (tamże: 92), występujące w funkcji motta niektórych rozdziałów pamiętnika bądź sentencji podsumowujących fragment opowiadania, nadają całości zapisu rozpatrywanej od strony formalnej piętno naiwnego prymitywu literackiego, tak przecież cenionego - niezależnie od faktograficznej wartości przekazu - przez czytelnika epoki romantyzmu4.

Wyniesione zapewne z lektur popularnych wówczas powieści czułych i równie częstych w użytku podręczników czułego listowania ${ }^{5}$ rudymenty sentymentalnej konwencji postrzegania i ujmowania rzeczywistości (przypadek Dmochowskiego prowadzącego przez pewien czas coś w rodzaju biura pisania listów miłosnych ${ }^{6}$ raczej wyklucza odwołania do kategorii światopoglądu jako

4 Na filiacje sentymentalizmu i „popularno-prowincjonalnego” realizmu w prozie po 1830 roku zwraca uwagę B. Dopart (2002: 166).

5 Istotę i rozwój czułej epistolografii początku XIX wieku charakteryzuje Alina Aleksandrowicz w artykule Preromantyczne listowanie jako forma ekspresji uczuć (1993: passim). Wielokrotnie wznawiany i wzorcowy dla tego okresu manuel épistolaire Christiana Gellerta nauczał korespondencji intymnej wyłącznie w konwencji sentymentalnej: „Es gibt eine muntre Art zu reden, die der Freundschaft und Liebe ins besondere eigen ist. Sie kommt mehr aus dem Innersten des Herzens, als aus dem Überflusse des Witzes her. Sie ist nicht so wohl sinnreich als naif. Man sagt seine wahre Meinung mit einer gewissen Sorglosigkeit, mit einer Offenherzigkeit, [...] und die doch gefält, weil sie aus einem freudigen und immer zufrieden Herzen quillt (Jest pewien żywy rodzaj mówienia, szczególnie właściwy dla przyjaźni i miłości. Pochodzi bardziej z wnętrza serca niż z obfitości dowcipu. Mniej w nim wyrozumowania niż naiwności. Wypowiada się w nim prawdziwe myśli z pewną niedbałością, prostodusznie, [...] a on się przecież podoba, ponieważ wypływa z radosnego i zadowolonego serca [przeł. A.T.])" (Gellert 1751: 106-107).

6 „Dmochowski za pewnym wynagrodzeniem pisywał listy miłośne do kochanek i kochanków, od kochanków i kochanek pisać nieumiejących. Wierny w dochowaniu powierzonej tajem- 
podstawy posługiwania się konwencją) dały o sobie znać w sposobie kształtowania narracji pamiętnikarskiej. Raz jeszcze warto zaznaczyć, że wzajemne przeplatanie się dwóch jej pasm - faktograficznego, dokumentującego historię ogółu, czyli tzw. wielką historię, oraz czułego, opowiadającego historię „serca”, czyli podmiotowo traktowanych dziejów doświadczenia wewnętrznego będącego udziałem narratorskiego "ja” - znane było w literaturze polskiej początku XIX wieku głównie za sprawą Grenadiera - filozofa. O ile jednak w powieści Godebskiego realizuje się ono z finezją, a nadto wątek miłosny nie odgrywa w fabule roli pierwszoplanowej i nie jest częścią bezpośrednich przeżyć wewnętrznych narratora (ten ostatni jedynie na zasadzie empatii dzieli miłosną udrękę tytułowego bohatera, opowiadającego o swoim uczuciu do ukochanej), o tyle w Pismach bytego wachmistrza ma, jak zazwyczaj to bywa w utworach artystycznie niewysublimowanych, postać schematu jasno konotującego podstawowe dla sentymentalizmu założenie twórcze - relacja o świecie zewnętrznym wobec jej podmiotu jest tym bogatsza, tym bardziej szczegółowa, im bardziej intensywne ze względu na wywołujący je obiekt jest doświadczenie wewnętrzne podmiotu.

Wrażliwe na literackie konwencje oko Koźmiana nie tylko dostrzegło ów schemat, lecz także ujrzało w nim możliwość celnego z praktycznego punktu widzenia sprofilowania całości edycji wspomnień eks-napoleończyka. Sprofilowania polegającego na sentymentalizacji zarówno autora pamiętnika, jak i samej inicjatywy wydawniczej przez odniesienie jej do naczelnych idei czułego światopoglądu.

Dmochowski-autor jawi się w Przedmowie Koźmiana jako niemal wzorowe ucieleśnienie czułego ideału mężczyzny. Uczuciowo wrażliwy doświadcza typowego dla sentymentalnej antropologii spod znaku Saint-Preux i Wertera poczucia odrzucenia, mającego niezmiennie dwa źródła: nieszczęśliwą miłość i społeczne (resp. towarzyskie) wykluczenie, wynikające z deklasacji lub przynależności do stanu trzeciego („Dmochowski, okryty ranami, ze starganym zdrowiem, dotknięty chorobą piersiową, nie mając ani sił, ani usposobienia do innej ręcznej pracy, chwycił się krawiectwa" [Koźmian 1843: 7]). Owemu stanowi towarzyszy jednak pokora w jego znoszeniu, zasadzająca się na stoicko ujętym przekonaniu o własnej, ewokowanej przez serce, racji moralnej, stanowiącej rodzaj pancerza chroniącego przed porażeniem złem:

nicy, zdolny wyrażać czucia tkliwe i namiętne, umiał pozyskać ufność kochających, i jak sam opowiada, nieraz wyciskał łzy i westchnienia, odczytując im listy, które w ich imieniu pisał, nieraz na nie pomyślne odpowiedzi sprowadzał, nieraz stał się niejako sprawcą uszczęśliwienia par miłośnych, a przy tym otworzył sobie źródło dochodu dość korzystne i niezawodne" (Koźmian 1843: 7-8). 
Dmochowski długie lata przepędził w niedostatku i niedoli, nigdy jednak powątpiewanie, niewiara, rozpacz nie zachwiały jego duszy. Zawsze uległy z pokorą wyrokom opatrzności, a ufny w jej łaskę, nawet wśród nędzy zachował wesołość i swobodę cnoty. [...] człowiek pracy, nawykły poddawać się bez szemrania woli Przedwiecznego, znoszący dolę niefortunną z męstwem, nawet ze swobodą umysłu, niedowierzający własnym zdolnościom, a jednak w sobie samym szukający obrony przeciw niesprawiedliwości losu [...]. (tamże: 8)

Wierność cnocie, czyli słuchanie i respektowanie głosu serca, skutkuje w obszarze życiowej praksis przede wszystkim, jak pisał autor Emila, „upodobaniem w dobru” i „czynieniem dobra” (Rousseau 1955: 125). Roussowskie pragnienie służenia dobru - jako najpierwotniejszy nakaz otwierającego się na swoje otoczenie czułego serca - w Koźmianowej kreacji napoleończyka-pamiętnikarza rysuje się w kontrastującym zestawieniu skromnego, cichego, utrzymującego rodzinę pracą własnych rąk „byłego wachmistrza” oraz - skrytego za powszechnymi „w tym czasie" przejawami egoizmu - duchowego stereotypu indywidualisty:

Trzeba by naszego pisarza-krawca widzieć w jego izdebce, obok żony i dziecka, trzeba by z nim chwilę rozmawiać i ujrzeć, że tak powiem, na własne oczy tę jego duszę tak zacną, tak bogobojną, tak ufną w miłosierdzie boskie i tak pełną świętej prostoty. Trzeba by na koniec dowiedzieć się o niektórych szczegółach jego życia, to jest o jego niedoli, które on wspomnieć w piśmie swoim zaniedbał, a które każde litościwe serce zająć są zdolne. [...] Nie bez korzyści moralnej może więc będzie wydanie pism Dmochowskiego w tym czasie, w którym żądze ludzkie są tak wygórowane, w którym mało kto poprzestaje na swoim, w którym niesmak i niespokojność gorączkowa jest chorobą niemal powszechną [...]. (Koźmian 1843: 7, 9).

Z kolei sentymentalizacja projektu edytorskiego eksponowanego przed czytelnikiem Przedmowy dokonuje się w wymiarach typowych dla konwencji sentymentalnych wydań prozy epistolarnej - formalnym, odsłaniającym relację między edytorem a tekstem, oraz aksjologicznym, ukazującym sferę wartości determinujących taki a nie inny stosunek wydawcy do obiektu jego zainteresowania. Koźmian jasno deklaruje swój szacunek wobec wydawanego tekstu: „[...] w rękopiśmie, który mi Dmochowski powierzył, słowa mego własnego nie dodałem, lecz niektóre w nim miejsca skróciłem, gdzieniegdzie wyraz jaki przemazałem, wiele wierszy mniej od prozy jego szczęśliwych opuściłem" (tamże: 10).

Podążając śladem swoich osiemnastowiecznych poprzedników, gwarantuje nienaruszalność przekazu mimo oczywistych, sygnalizowanych wprost powodów 
do edytorskiej ingerencji: „[...] nie chcąc zetrzeć z pracy Dmochowskiego barwy jemu właściwej, nie dozwalałem pióru przekreślać i poprawiać tego nawet, co mi się do poprawienia zdawało [...]" (tamże: 11$)$.

Pełne zachowanie językowo-stylistycznej strony kierowanego do druku tekstu wraz z zawartymi w nim błędami i naruszeniami zasady dobrego smaku ma tylko jedno formalne wytłumaczenie - czytelnik musi obcować z autentycznym, niezafałszowanym przez korektorskie zabiegi przekazem autorskim, gdyż tylko wtedy może zajść w pełni akt sentymentalnie rozumianej komunikacji, tylko wtedy serce może mówić do serca ${ }^{7}$.

Wymiar aksjologiczny tej wydawniczej inicjatywy Koźmiana ujawniają stwierdzenia w rodzaju:

Łatwo czytelnik w ciągu tego dziełka dostrzeże, jak wiele jeszcze w stylu, w szy$\mathrm{ku}, \mathrm{w}$ toku pisma do zupełnego wykształcenia brakuje [...]. W opowiadaniu Dmochowskiego znajdzie się także zapewne wiele błędów i omyłek historycznych, chronologicznych, geograficznych; łatwo byłoby je sprostować, lecz i od tego wstrzymałem się, chcąc dać poznać pisarza naszego w całej jego prostocie, szczerości i częstokroć niewiadomości żołnierza. (tamże)

Wydawca bardziej niż literackość (resp. artystyczną poprawność) ceni prymitywizm publikowanej wypowiedzi, bardziej niż faktograficzną wierność zawartych w niej przedstawień - autentyzm podmiotowego punktu widzenia, dopuszczający zniekształcenia w opisie rzeczywistości. Ceni je bardziej, a tym samym nie bierze w rachubę krytycznego dystansu wobec edytowanego tekstu, gdyż nie tylko wie, mówiąc słowami Rousseau (1962: 413), że „książki tej nie napisano po to, aby krążyła po świecie, [...] niewielu czytelnikom będzie [ona - A.T.] odpowiadać; styl odstraszy ludzi kierujących się smakiem, treść przerazi poważnych", lecz także wierne oddanie głosu serca czyni swoją edytorską powinnością.

Dodać w tym miejscu należy, że jeszcze przed opublikowaniem Pism bytego wachmistrza Koźmian w liście przesłanym do „Biblioteki Warszawskiej”, anonsującym odkrycie wspomnień przemyskiego „majstra krawieckiego”, potraktował przekaz Dmochowskiego jako typowo sentymentalny komunikat, obliczony na

7 Istotę sentymentalnego aktu komunikacji, dokonującego się jakby ponad tekstem, czyli upodrzędniającego nośnik komunikatu, a zatem relatywizującego l'art d’écrire, celnie ujął Jean Starobinski (2000: 170-171): „Rousseau bez przerwy buntuje się przeciwko sztuce pisarskiej. [...] Tak naprawdę liczy się tylko zamiar, który jest niezależny od wszelkich słów; to »stan duszy « czytelnika po lekturze, stan, który stanowi odbicie stanu duszy autora sprzed aktu pisania. Rousseau chwyta więc za pióro po to tylko, aby odesłać czytelnika do uczucia, które poprzedza w domyśle moment pisania albo które wyłania się z pisanego tekstu". 
wywołanie współbrzmienia w sferze uczuć odbiorcy: „Najcelniejszą pisma tego zaletę stanowią bogobojne, prawe i szlachetne uczucia pisarza. Wszędzie on je objawia, czytelnika przywięzuje do siebie" (Koźmian 1842: 654-655).

Przytoczone deklaracje Koźmiana, zaświadczające o w pełni aprobatywnym nastawieniu w stosunku do formy publikowanego przekazu, jego komunikacyjnej skuteczności i moralnej wartości, korespondują wyraźnie z wzorcową dla większości - najczęściej literacko fingowanych - wydań czułych listów, pamiętników, diariuszy postawą edytorską, w większości przypadków podobnie jak przedmiot edycji fingowaną, upowszechnioną dzięki powieści Goethego (1984: 5): „Czego tylko dowiedzieć się mogłem o dziejach biednego Wertera, zebrałem pilnie i podaję wam tutaj - i wiem, że będziecie mi wdzięczni. Nie możecie odmówić jego duchowi i charakterowi podziwu i miłości, a jego losom łez" ${ }^{\text {. }}$.

Pisma bytego wachmistrza nie stały się polskim „Werterem” późnego sentymentalizmu, gdyż - rzecz jasna - nie mogły nim się stać. Ich formalna wtórność wobec znanych od ponad półwiecza schematów literackich i skonwencjonalizowany styl narracji przesłaniały - wbrew temu, czego spodziewał się Koźmian - ceniony przez czytelników prozy sentymentalno-wspomnieniowej autentyzm ujawnianych myśli i uczuć podmiotu piszącego, w tym przypadku nieskomplikowanych zresztą i w swej treści mało oryginalnych. Jednak dla historyka literatury wspomnienia Dmochowskiego są jeszcze jednym świadectwem żywotności sentymentalizmu na początku lat 40. XIX wieku.

\section{BIBLIOGRAFIA}

Aleksandrowicz, A. (1993). Preromantyczne listowanie jako forma ekspresji uczuć. Pamiętnik Literacki, nr 2, 66-83.

Constant, B. (1948). Słówko od wydawcy. W: tegoż, Adolf. Warszawa: Spółdzielnia Wydawnicza „Wiedza”.

Czajkowska, K. (1987). Wstęp. W: A. Fredro, Trzy po trzy. Warszawa: PIW.

Dmochowski, F.W. (1843). Pisma byłego wachmistrza w wojskach pięciu różnych mocarstw, dziś majstra krawieckiego w Przemyślu. Wydane przez A.E. Koźmiana. Lwów: Drukarnia Piotra Pillera.

Dopart, B. (2002). Nasz literacki wiek XIX i „izmy”. W: Z. Trojanowiczowa, K. Trybuś (red.), Na poczatku wieku. Rozważania o tradycji (s. 147-170). Poznań: Wydawnictwo Poznańskiego Towarzystwa Przyjaciół Nauk.

8 W opublikowanym w 1816 roku Adolfie Beniamina Constanta (1948: 28-29), będącym niejako „nowym Werterem” XIX wieku, fingowany wydawca powołuje się na list skłaniający go do czynności edytorskich i składa podobną, jak wyżej cytowane, deklarację: „List ten skłonił mnie do ogłoszenia rękopisu, dając pewność, iż nie może to obrazić ani narazić nikogo. Nie zmieniłem $\mathrm{w}$ oryginale ani słowa [...]". 
Gellert, Ch.F. (1751). Briefe, nebst einer praktischen Abhandlung von dem guten Geschmacke in Briefen. Leipzig: Johann Wendler.

Goethe, J.W. (1984). Cierpienia mtodego Wertera. Warszawa: PIW.

Herrlinger, W. (1987). Sentimentalismus und Postsentimentalismus. Studien zum englischen Roman bis zur Mitte des 19. Jahrhunderts. Tübingen: De Gruyter.

Jończyk, A. (2014). Sentymentalizm a preromantyzm. Konteksty Kultury, t. 11(3), 205216, DOI: https://doi.org/10.4467/23531991KK.14.012.2873.

Kleiner, J. (1975). Sentymentalizm i preromantyzm. Studia inedita z literatury porozbiorowej 1795-1822. Kraków: Wydawnictwo Literackie.

Kostkiewiczowa, T. (1981). Tradycja sentymentalizmu w poezji epoki romantycznej. Zarys problemu. W: M. Żmigrodzka (red.), Problemy polskiego romantyzmu (s. 143-162). Wrocław: Ossolineum.

Koźmian, A.E. (1842). [List do redakcji]. Biblioteka Warszawska, t. 4, 654-655.

Koźmian, A.E. (1843). Przedmowa wydawcy. W: F.W. Dmochowski, Pisma bytego wachmistrza w wojskach pięciu różnych mocarstw, dziś majstra krawieckiego w Przemyślu. Wydane przez A.E. Koźmiana. Lwów: Drukarnia Piotra Pillera.

Rousseau, J.-J. (1955). Emil, czyli O wychowaniu (T. 2). Wrocław: Zakład Narodowy im. Ossolińskich.

Rousseau, J.-J. (1962). Przedmowa. W: tegoż, Nowa Heloiza. Wrocław: Zakład Narodowy im. Ossolińskich.

Sill, G. (2016). Developments in Sentimental Fiction. W: J.A. Downie (ed.), The Oxford Handbook of the Eighteenth-Century Novel (s. 426-439). Oxford: OUP Oxford.

Starobinski, J. (2000). Jean-Jacques Rousseau. Przejrzystość i przeszkoda oraz siedem esejów o Rousseau. Warszawa: Wydawnictwo KR.

Zgorzelski, C. (1949). Duma - poprzedniczka ballady. Toruń: Towarzystwo Naukowe w Toruniu. 